\title{
PERBANDINGAN NILAI TUKAR PETANI (NTP) ANTAR SUBSEKTOR PERTANIAN DI INDONESIA
}

\author{
Maria Pangestika ${ }^{1)}$ dan Tinjung Mary Prihtanti ${ }^{2)}$ \\ ${ }^{1)}$ Fakultas Pertanian dan Bisnis, Program Magister Ilmu Pertanian, Universitas Kristen Satya Wacana, Jl. \\ Diponegoro No. 52-60 Salatiga, HP: 0812-2982-8566, \\ email: mariapangestika@gmail.com \\ ${ }^{2)}$ Fakultas Pertanian dan Bisnis, Program Studi Agribisnis,Universitas Kristen Satya Wacana, Jl. Diponegoro \\ No. 52-60 Salatiga, HP: 0815-6580-993, email: tinjung.murjono@gmail.com
}

\begin{abstract}
ABSTRAK
Sektor pertanian menjadi salah satu target pembangunan nasional Indonesia dalam Rencana Pembangunan Jangka Menengah Nasional 2015-2019 karena dianggap sebagai sektor strategis secara ekonomi. Keberhasilan pembangunan di sektor pertanian salah satunya dapat dilihat dari tingkat kesejahteraan petani yang umumnya ditentukan dari Nilai Tukar Petani (NTP). Artikel ini ditulis untuk memaparkan tingkat kesejahteraan petani pada 3 subsektor pertanian yaitu pertanian tanaman pangan, tanaman perkebunan dan tanaman hortikultura dengan cara membandingkan besarnya NTP pada masing-masing subsektor. Data yang digunakan merupakan data sekunder tahun 2015-2019 yang berasal dari Badan Pusat Statistik (BPS). Hasil analisis menunjukkan bahwa NTP tanaman pangan, tanaman perkebunan dan tanaman hortikultura mengalami fluktuasi dan NTP tanaman hortikultura paling stabil diantara yang lainnya. Urutan rata-rata NTP dari yang terbesar hingga terkecil adalah tanaman hortikultura diurutan pertama dengan rata-rata per tahun sebesar 101,91, diurutan kedua adalah tanaman pangan yaitu sebesar 101,37 dan urutan terakhir adalah tanaman perkebunan yaitu sebesar 97,29.
\end{abstract}

Kata kunci: kesejahteraan petani, nilai tukar petani, pembangunan sektor pertanian

\section{ABSTRACT}

The agricultural sector is one of Indonesia's national development targets in Rencana Pembangunan Jangka Menengah Nasional 2015-2019 because it is considered an economic strategic sector. One of the success of development in the agricultural sector can be seen from the level of farmer's welfare which is generally determined by the Nilai Tukar Petani (NTP). This article was written to explain the level of welfare of farmers in 3 agricultural sub-sectors, namely food crop agriculture, estate crops and horticultural crops by comparing the amount of NTP in each subsector. The data used are secondary data from 2015-2019 from the Badan Pusat Statistik (BPS). The results of the analysis showed that the NTP of food crops, estate crops and horticultural crops experienced fluctuations and the NTP of horticultural plants was the most stable among the others. The average order of NTP from the largest to the smallest is the first ranked horticultural crop with an average annual rate of 101,91, the second sequence is food plants that is equal to 101,37 and the last sequence is plantation crops that amount to 97,29.

Keywords: agricultural sector development, farmer exchange rates, farmers' welfare

\section{PENDAHULUAN}

Negara Indonesia dalam Rencana Pembangunan Menengah Nasional Tahun 2015-2019 menyatakan agenda pembangunan nasionalnya yang meliputi: (1) Peningkatan Kedaulatan Pangan; (2) Peningkatan Ketahanan Air; (3) Peningkatan
Kedaulatan Energi; (4) Melestarikan Sumber Daya Alam, Lingkungan Hidup dan Pengelolaan Bencana; (5) Pengembangan Ekonomi Maritim dan Kelautan; (6) Penguatan Sektor Keuangan; dan (7) Penguatan Kapasitas Fiskal Negara. Ketujuh agenda 
tersebut merupakan upaya dalam mewujudkan kemandirian ekonomi melalui penggerakan sektor-sektor strategis ekonomis.

Peningkatan kedaulatan pangan menjadi salah satu fokus rencana pembangunan menengah Indonesia, yang mana kedaulatan pangan erat berhubungannya dengan sektor pertanian, sehingga dapat dinyatakan bahwa sektor pertanian menjadi salah satu sektor strategis secara ekonomi dalam pembangunan negara Indonesia. Pertanian dalam arti sempit meliputi pertanian subsektor tanaman pangan, subsektor tanaman perkebunan dan subsektor tanaman hortikultura.

Keberhasilan pembangunan di sektor pertanian dapat dilihat salah satunya dari tingkat kesejahteraan petani yang diukur dari Nilai Tukar Petani (NTP). NTP merupakan perbandingan antara indeks harga yang diterima petani dengan indeks harga yang dibayarkan petani.

Artikel ini ditulis untuk memaparkan tingkat kesejahteraan petani dalam rangka pembangunan nasional dengan cara membandingkan pertumbuhan NTP pada 3 subsektor pertanian yaitu subsektor tanaman pangan, subsektor tanaman perkebunan dan subsektor tanaman hortikultura di Indonesia.

\section{METODE KAJIAN}

Analisis ini dibuat dengan menggunakan data sekunder yang berasal dari Badan Pusat Statistik (BPS) berupa data tahunan dari 2015-2019.

Pertumbuhan NTP per subsektor dihitung dengan membandingkan selisih NTP tahun akhir dengan NTP tahun awal dengan NTP tahun awal dikalikan seratus persen. Pertumbuhan NTP dirumuskan sebagai berikut:

Keterangan:

$$
\frac{N T P n-N T P o}{N T P o} \times 100 \%
$$

NTPn = Nilai Tukar Petani tahun akhir NTPo = Nilai Tukar Petani tahun awal
Besarnya nilai NTP mengandung beberapa arti, yaitu sebagai berikut:

1. NTP $>100$, berarti petani mengalami surplus. Harga produksi naik lebih besar dari kenaikan harga konsumsinya. Pendapatan petani naik lebih besar dari pengeluarannya.

2. NTP $=100$, berarti petani mengalami impas. Kenaikan/penurunan harga produksinya sama dengan persentase kenaikan/penurunan harga barang konsumsi. Pendapatan petani sama dengan pengeluarannya.

3. NTP $<100$, berarti petani mengalami defisit. Kenaikan harga produksi relatif lebih kecil dibandingkan dengan kenaikan harga barang konsumsinya. Pendapatan petani turun, lebih kecil dari pengeluarannya.

\section{HASIL DAN PEMBAHASAN}

\section{Dinamika Nilai Tukar Petani (NTP)}

NTP tanaman pangan, tanaman perkebunan dan tanaman hortikultura dihitung dari indeks harga yang diterima petani (IHT) dibandingkan dengan indeks harga yang dibayar petani (IHB).IHT sektor tanaman pangan dihitung dari subsektor tanaman padi dan tanaman palawija, untuk sektor tanaman perkebunan adalah tanaman perkebunan dan untuk sektor tanaman hortikultura meliputi subsektor tanaman buah dan tanaman sayur.

IHB petani dihitung berdasarkan pengeluaran untuk konsumsi dan pengeluaran bukan untuk konsumsi. Pengeluaran untuk konsumsi meliputi konsumsi bahan makanan; makanan jadi; sandang; perumahan; kesehatan; pendidikan, rekreasi dan olahraga; serta transportasi. Pengeluaran bukan untuk konsumsi meliputi pengeluaran untuk bibit; obat-obatan dan pupuk; transportasi; sewa lahan dan pajak; penambahan barang modal; serta upah buruh tani. IHB untuk sektor tanaman pangan, tanaman perkebunan dan tanaman hortikultura adalah sama.

Gambar 1. menggambarkan fluktuasi nilai tukar petani (NTP) tanaman pangan, 
tanaman perkebunan dan tanaman hortikultura. Fluktuasi NTP tanaman hortikultura cenderung lebih stabil dibandingkan fluktuasi tanaman pangan dan tanaman perkebunan. Tahun 2017 merupakan titik balik NTP tanaman pangan dan tanaman perkebunan karena setelah tahun 2017 NTP tanaman pangan mengalami lonjakan kenaikan yang sangat drastis, sedangkan NTP tanaman perkebunan mengalami penurunan.

Selain fluktuasinya yang lebih stabil, NTP tanaman hortikultura selalu lebih besar dari NTP tanaman perkebunan selama periode tahun 2015-2019, dibandingkan dengan tanaman pangan, NTP tanaman hortikultura selalu lebih besar sampai tahun 2017 dan pada tahun 2018-2019 NTP tanaman pangan menjadi yang terbesar.

Diantara ketiga subsektor pertanian, besarnya NTP (lihat Tabel 1.) tanaman perkebunan selalu kurang dari 100 selama periode 2015-2019 dengan rata-rata per tahun sebesar 97,29 sedangkan NTP tanaman pangan berfluktuasi, dimana tahun 2016 dan 2017 besarnya NTP tanaman pangan kurang dari 100 dan pada tahun 2015, 2018 dan 2019 berada di atas 100 dengan rata per tahun sebesar 101,37. NTP tanaman hortikultura selama periode $2015-2019$ selalu berada di atas 100 dengan rata-rata 101,91.

Sekalipun pada tahun-tahun tertentu besarnya NTP tanaman pangan, tanaman perkebunan dan tanaman hortikultura berada di atas 100 yang berarti mengalami surplus, namun surplus yang diterima petani tergolong kecil karena besarnya surplus hanya berkisar di antara 1 - 2 dari titik impasnya yaitu 100 . Kondisi ini berkaitan dengan faktor penentu NTP yaitu IHT dan IHB.

Gambar 2, 3 dan 4 menggambarkan dinamika antara IHT, IHB dan NTP tanaman pangan, tanaman perkebunan dan tanaman hortikultura dimana ditemukan kesamaan bahwa besarnya IHT dan IHB hampir sama sehingga Gambar keduanya cenderung berhimpitan. Hal inilah yang menyebabkan surplus yang diterima petani kecil, karena sekalipun indeks harga yang diterima petani (IHT) meningkat, indeks harga yang dibayar petani (IHB) juga meningkat.

Gambar 2, 3, dan 4 juga menunjukkan kesamaan pola dimana pola NTP cenderung mengikuti pola IHT, apabila IHT meningkat maka NTP meningkat, begitu pula ketika IHT menurun makan NTP akan menurun.

\section{Pertumbuhan Nilai Tukar Petani (NTP) Per Subsektor}

Pertumbuhan NTP tanaman pangan, tanaman perkebunan dan tanaman hortikultura disajikan dalam Tabel 2., dapat diketahui bahwa NTP dari ketiga sektor tersebut mengalami fluktuasi, namun tanaman pangan cenderung meningkat, sedangkan tanaman perkebunan cenderung menurun dan tanaman hortikultura cenderung lebih stabil.

Tahun 2016 NTP tanaman pangan mengalami penurunan dari tahun sebelumnya yaitu sebesar 0,87\%. Tahun 2017 kembali terjadi penurunan, bahkan jumlah penurunannya lebih besar dari tahun sebelumnya yaitu sebesar $1,01 \%$. Tahun 2018 NTP tanaman pangan mengalami peningkatan yang besar yaitu sebanyak 4,55\% dan tahun 2019 (hingga bulan Nopember) kembali meningkat sebesar $2,53 \%$.

Berbanding terbalik dengan NTP tanaman pangan, NTP tanaman perkebunan justru mengalami peningkatan di tahun 2016 dan 2017 sedangkan pada tahun 2018 dan 2019 terjadi penurunan. Tahun 2016 NTP tanaman perkebunan tumbuh sebesar $0,69 \%$ dan tahun 2017 sebesar 1,08\%. Pada tahun 2018 NTP tanaman perkebunan turun sebesar $1,29 \%$ dan $2,83 \%$ pada tahun 2019 . NTP tanaman hortikultura tumbuh sebesar $1,12 \%$ pada tahun 2016 , selanjutnya menurun sebesar $0,99 \%$ dan pada tahun 2018 kembalimenurun sebesar $0,65 \%$, selanjutnya 
pada tahun 2019 terjadi peningkatan sebesar $1,20 \%$.

Jika diperhatikan, Gambar 1. maupun Tabel 1. menunjukkan bahwa tahun 2017 sebagai titik balik bagi pertumbuhan NTP tanaman pangan dan titik balik bagi penurunan NTP tanaman perkebunan, karena setelah tahun 2017 NTP tanaman pangan terus meningkat dan NTP tanaman perkebunan terus menurun.

\section{DAFTAR PUSTAKA}

Badan Pusat Statistik (BPS). 2019. Berita Resmi Statistik: Keadaan Ketenaga kerjaan Indonesia Februari 2019. Jakarta: BPS.

Badan Pusat Statistik (BPS). 2019. Tenaga Kerja:

https://www.bps.go.id/subject/6/tenagakerja.html\#subjekViewTab3. Diakses pada 30 September 2019 pukul 20.00 WIB.

\section{KESIMPULAN}

Hasil analisis menunjukkan bahwa NTP tanaman pangan, tanaman perkebunan dan tanaman hortikultura mengalami fluktuasi dan NTP tanaman hortikultura paling stabil diantara yang lainnya.Urutan rata-rata NTP dari yang terbesar hingga terkecil adalah tanaman hortikultura diurutan pertama dengan rata-rata per tahun sebesar 101,91, diurutan kedua adalah tanaman pangan yaitu sebesar 101,37 dan urutan terakhir adalah tanaman perkebunan yaitu sebesar 97,29 .

Badan Pusat Statistik (BPS). 2019. Nilai Tukar Petani:https://www.bps.go.id/subject/22/ nilai-tukar-petani.html\#subjekViewTab3. Diakses pada 30 September 2019 pukul 20.00 WIB

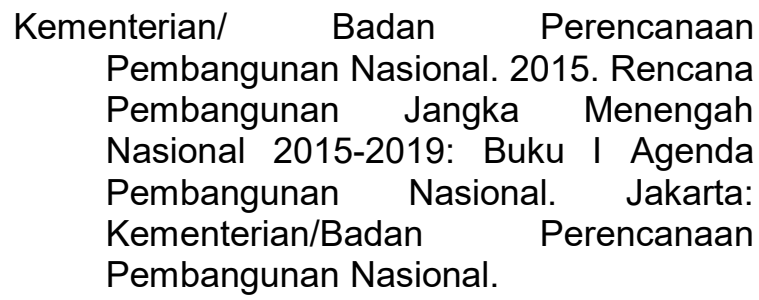




\section{LAMPIRAN}

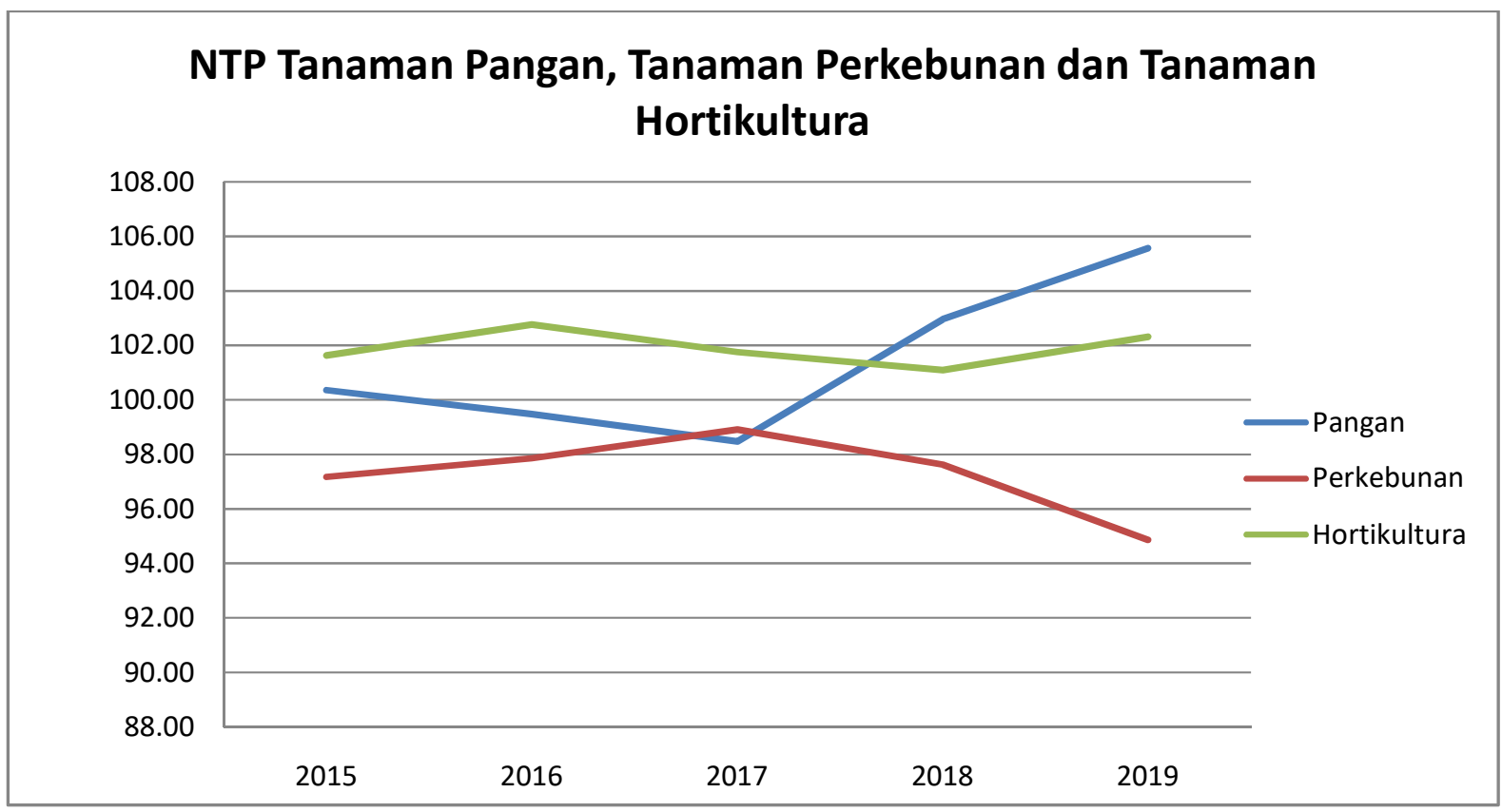

Gambar 1. Dinamika Nilai Tukar Petani Tanaman Pangan, Tanaman Perkebunan, dan Tanaman Hortikultura di Indonesia Tahun 2015-2019

Sumber: BPS diolah

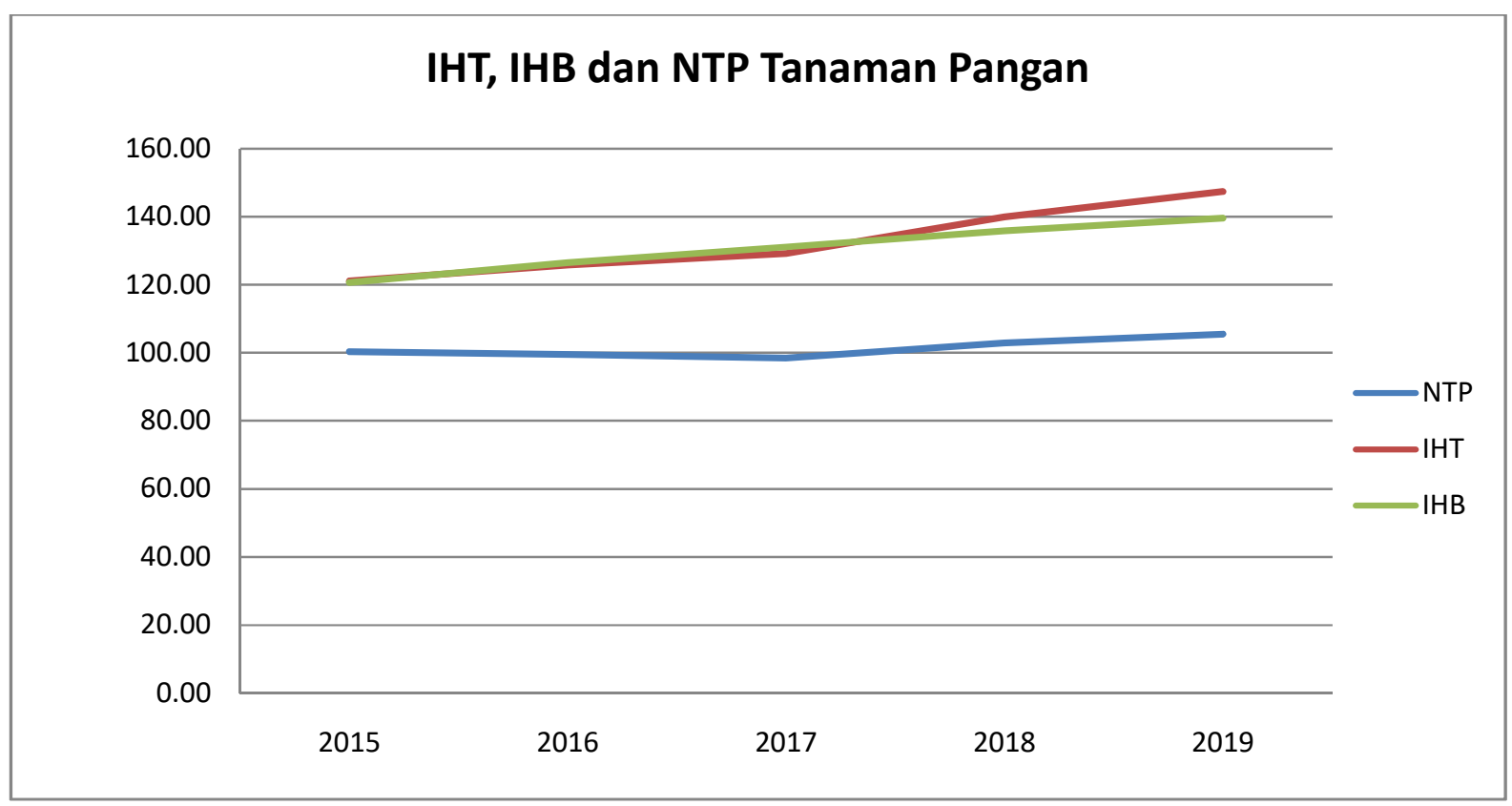

Gambar 2. IHT, IHB dan NTP Tanaman Pangan di Indonesia Tahun 2015-2019 Sumber: BPS diolah 
Pangestika \& Prihtanti. 2020

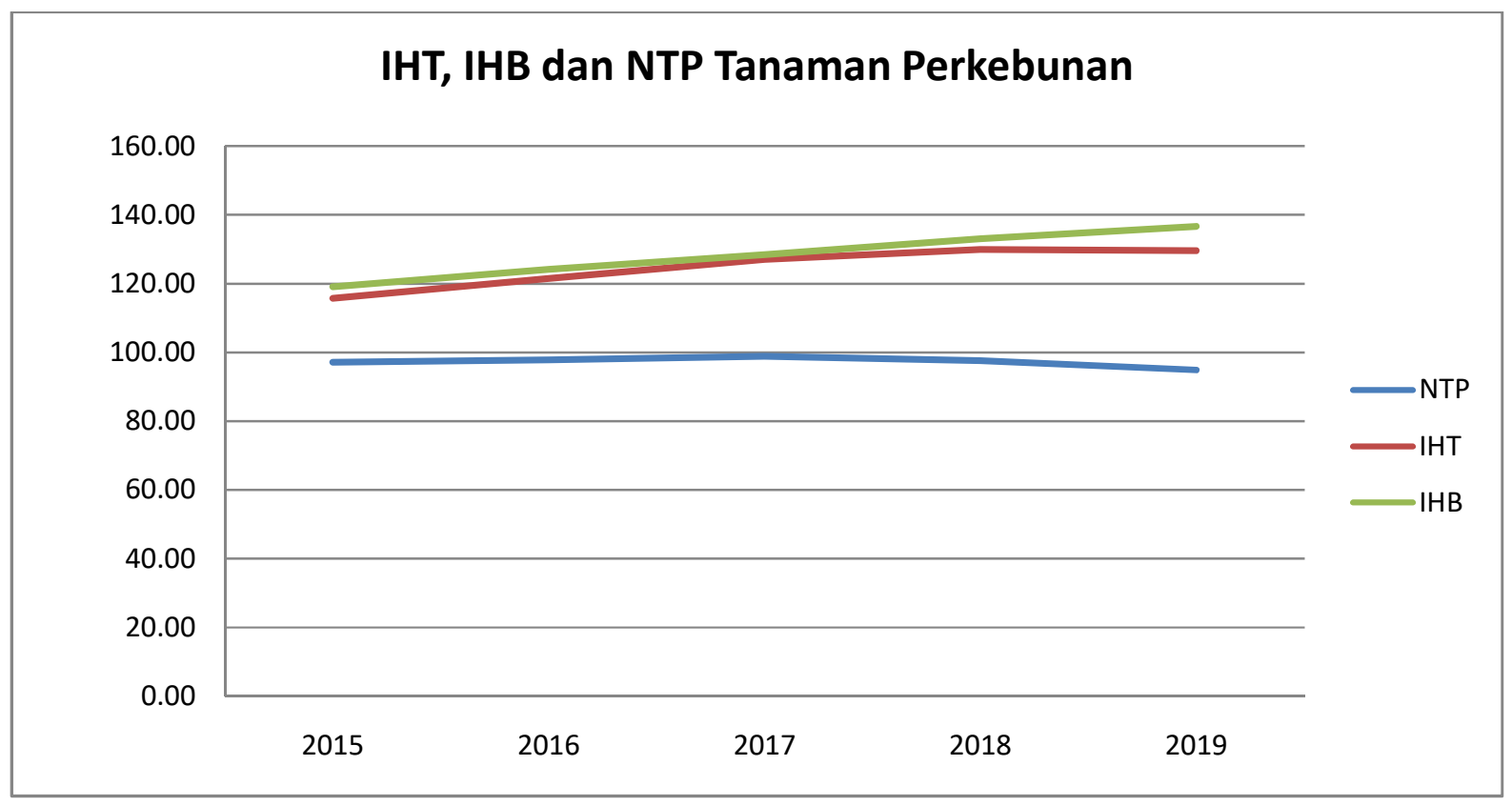

Gambar 3. IHT, IHB dan NTP Tanaman Perkebunan di Indonesia Tahun 2015-2019 Sumber: BPS diolah

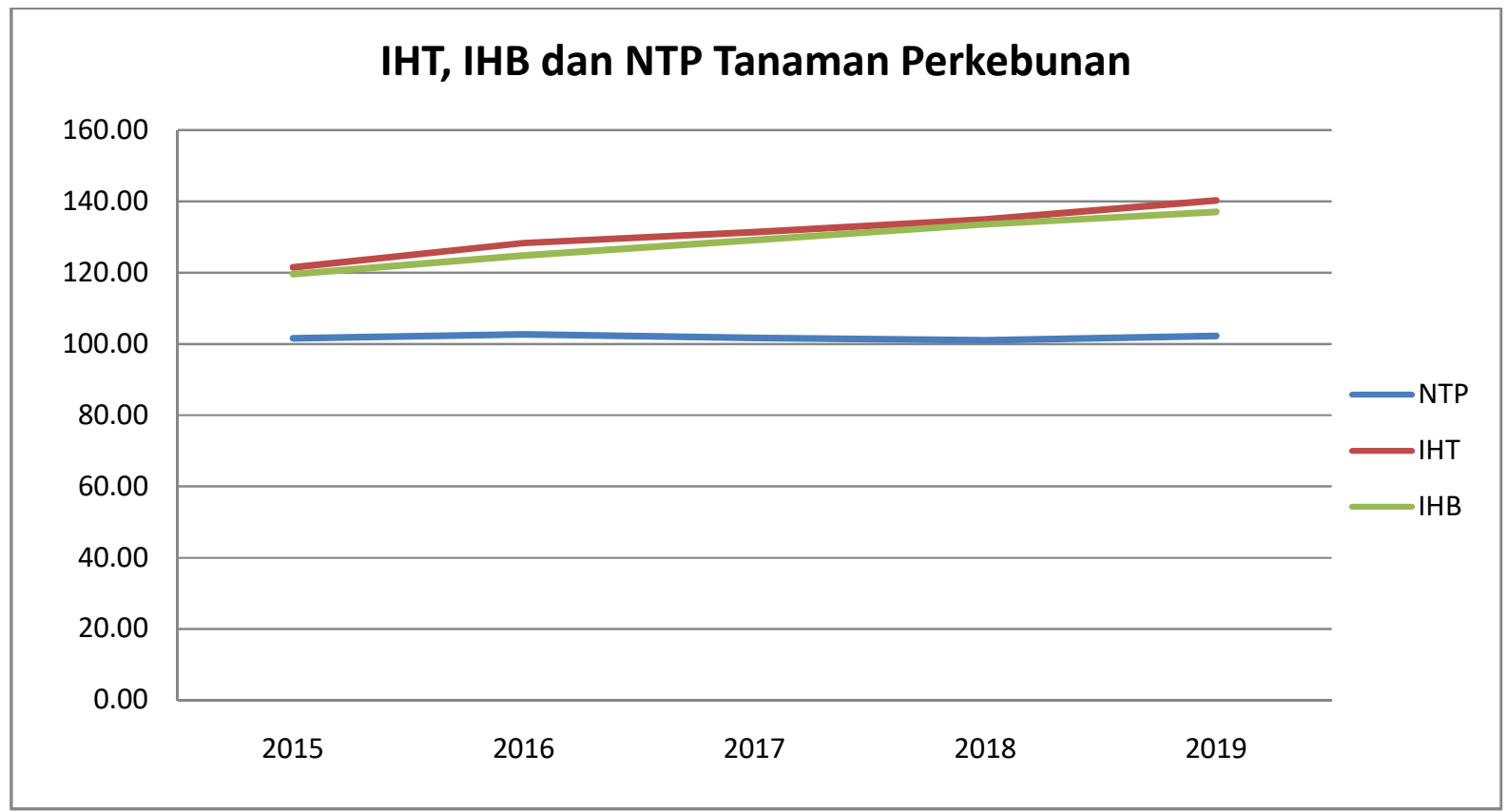

Gambar 4. IHT, IHB dan NTP Tanaman Hortikultura di Indonesia Tahun 2015-2019 Sumber: BPS diolah 
Pangestika \& Prihtanti. 2020

Tabel 1. NTP Tanaman Pangan, Perkebunan dan Hortikultura

\begin{tabular}{cccc}
\hline Tahun & Pangan & Perkebunan & Hortikultura \\
\hline 2015 & 100,35 & 97,18 & 101,63 \\
2016 & 99,48 & 97,85 & 102,77 \\
2017 & 98,48 & 98,91 & 101,75 \\
2018 & 102,96 & 97,63 & 101,09 \\
2019 & 105,56 & 94,87 & 102,31 \\
\hline Rata-rata & 101,37 & 97,29 & 101,91
\end{tabular}

Sumber: BPS diolah

Tabel 2. Pertumbuhan NTP Tanaman Pangan, Tanaman Perkebunan dan Tanaman Hortikultura di Indonesia Tahun 2015-2019

\begin{tabular}{lcccc}
\hline \multirow{2}{*}{ Sektor } & \multicolumn{4}{c}{ Pertumbuhan NTP (\%) } \\
\cline { 2 - 5 } & $2015-2016$ & $2016-2017$ & $2017-2018$ & $2018-2019$ \\
\hline Tanaman Pangan & $-0,87$ & $-1,01$ & 4,55 & 2,53 \\
Tanaman Perkebunan & 0,69 & 1,08 & $-1,29$ & $-2,83$ \\
Tanaman Hortikultura & 1,12 & $-0,99$ & $-0,65$ & 1,20 \\
\hline
\end{tabular}

Sumber: BPS diolah 